\title{
Role of the Dopamine Transporter in the Differential Cocaine-Induced Locomotor Activation of Inbred Long-Sleep and Short-Sleep Mice
}

\author{
Taleen Hanania*,', Joshua M Gulley', Danielle O Salaz', Gaynor A Larson' and Nancy R Zahniser' \\ 'Department of Pharmacology, Neuroscience Program and School of Pharmacy, University of Colorado Health Sciences Center, Denver, CO, USA
}

\begin{abstract}
The locomotor-stimulant effects of cocaine, mediated through inhibition of the dopamine transporter (DAT), can be influenced by environmental factors. Previously, we found that following a short exposure to the testing environment, cocaine induces greater locomotor activation in inbred long-sleep (ILS) mice, compared to inbred short-sleep (ISS) mice. In the present study, all animals received prolonged habituation to the testing chambers prior to cocaine injection, and the results were compared with those from our previous study. When mice were tested with saline on day I and with either saline or cocaine $(10-20 \mathrm{mg} / \mathrm{kg})$ on day 2, we observed significant locomotor stimulation in ILS, but not ISS, mice at all tested doses of cocaine. Thus, prolonged habituation does not alter the differential responsiveness of these two strains of mice to cocaine. We found no strain differences in striatal cocaine levels. However, $\left.{ }^{3} \mathrm{H}\right] \mathrm{WIN}$ 35,428 binding studies showed a lower number of striatal DATs in ILS, compared to ISS, mice. In vivo analysis of striatal DAT activity revealed not only that ILS mice cleared exogenously applied DA more slowly than ISS mice, but also that cocaine $(10 \mathrm{mg} / \mathrm{kg})$ decreased DA clearance selectively in ILS mice. Thus, functional differences in striatal DATs between ILS and ISS mice likely contribute to the differential behavioral activation of cocaine in these two mouse strains.

Neuropsychopharmacology (2004) 29, I8I4-1822, advance online publication, 16 June 2004; doi: I0. I038/sj.npp. 130050 I
\end{abstract}

Keywords: cocaine; behavior; dopamine transporter; electrochemistry; mice; striatum

\section{INTRODUCTION}

In humans, initial sensitivity to a drug of abuse can be used as a marker for liability to drug addiction (Haertzen $e t$ al, 1983). Studies have found that genetic factors contribute to the marked variability among humans in their responsiveness to the reinforcing effects of cocaine and influence the vulnerability of individuals to become cocaine abusers (Cadoret et al, 1986; Luthar and Rounsaville, 1993; Merikangas et al, 1998). Furthermore, a family history positive for alcoholism has been associated with increased risk for cocaine addiction (Smith, 1986), suggesting that similar genes underlie the co-morbidity of alcohol and cocaine abuse.

Pharmacogenetic studies in C57 and DBA mice support the above-mentioned hypothesis as these mouse lines exhibit parallel differential sensitivity to the locomotorstimulant effects of both ethanol and cocaine, with C57 mice exhibiting less locomotion to both drugs (Rocha et al, 1998;

*Correspondence: Dr T Hanania, Department of Pharmacology, C-236, University of Colorado Health Sciences Center, 4200 E Ninth Ave, Denver, CO 80262, USA, Tel: + | 303315 52।I, Fax: + I 303 3 I 5 7097, E-mail: Taleen.Hanania@UCHSC.edu

Received 3 April 2004; revised 5 March 2004; accepted 5 May 2004 Online publication: 5 May 2004 at http://www.acnp.org/citations/ Npp050600404 I0I/default.pdf
Tolliver and Carney, 1995; Womer et al, 1994). However, this is not the case with all mouse lines. For example, FAST and SLOW mice were selected for their higher and lower, respectively, locomotor response to ethanol (Phillips et al, 1992). The replicate line FAST-1 mice also show higher ethanol-, cocaine-, and methamphetamine-induced locomotor activity compared to SLOW-1 mice (Bergstrom et al, 2003). However, no differences in cocaine-stimulated locomotor activity were found between FAST-2 and SLOW-2 mice (Bergstrom et al, 2003). Long-sleep (LS) and short-sleep (SS) mice were selected for their differential initial sensitivity to the sedative effects of a high dose of ethanol (McClearn and Kakihana, 1981). They also exhibit differential sensitivity to the locomotor-stimulant effects of low doses of ethanol, with SS mice exhibiting greater locomotor activation, compared to LS mice (DeFries et al, 1989; Dudek and Phillips, 1990). However, studies determining the sensitivity of these mice to cocaine have yielded disparate results that appear to depend on whether or not the mice were habituated to the testing environment (De Fiebre et al, 1989; George and Ritz, 1990; Jones et al, 1991). George and Ritz (1990) found that without habituation SS mice exhibited more cocaine-induced locomotor activity than LS mice, whereas Jones et al (1991) used a 2-day testing paradigm and found that LS and SS mice that had been injected with saline on day 1 exhibited similar 
locomotor activation to cocaine on day 2. Together, these studies reinforce the notion that while drugs of abuse may target some common neuronal pathways, independent mechanisms such as environmental influences are also involved in initial responsiveness (Phillips et al, 1996).

Inbred LS (ILS) and SS (ISS) mice, derived from LS and SS sibling matings, also are differentially sensitive to the hypnotic effects of ethanol, with ILS mice exhibiting longer loss of righting reflex than ISS mice (Markel et al, 1995). On the other hand, low doses of ethanol induce greater locomotor activation in ISS mice, compared to ILS mice (Hanania and Zahniser, 2002). However, an effect opposite to ethanol is seen with cocaine: ILS mice exhibit more locomotor activation than ISS mice (Hanania and Zahniser, 2002). In these experiments, the behavioral testing was carried out following a short habituation period (60 min).

Cocaine inhibits monoamine transporters (Ritz et al, 1990) and increases synaptic levels of dopamine (DA), serotonin (5-HT), and norepinephrine (NE). The behavioral effects of cocaine have been most often associated with the mesolimbic and nigrostriatal DA systems (Kuhar et al, 1991; Morse et al, 1995; Miner, 1997). Both nucleus accumbens (NAc) and striatum (ie, dorsal striatum) have been shown to be involved in the locomotor-stimulant effects of cocaine and amphetamine (Delfs et al, 1990; Heusner et al, 2003; Mao and Wang, 2000; Willuhn et al, 2003). Furthermore, cocaine increases extracellular DA levels in both NAc and striatum (Di Chiara and Imperato, 1988; He and Shippenberg, 2000).

Our laboratory has shown that outbred male SpragueDawley rats can be profiled as high or low cocaine responders, based on their initial behavioral responsiveness to an acute low dose of cocaine $(10 \mathrm{mg} / \mathrm{kg}$ ) (Gulley et al, 2003; Sabeti et al, 2002). Furthermore, the differential behavioral responsiveness of the high and low responders to cocaine is accompanied by functional differences in DATs in NAc and striatum (Sabeti et al, 2002). It is possible that similar differences in DAT function may also contribute to the differences in cocaine-induced behavior observed in ILS and ISS mice.

In order to further investigate the differential locomotor responsiveness of ILS and ISS mice to cocaine, we first tested whether minimizing the novelty of the behavioral test chamber would alter the differential behavioral cocaine responsiveness from that previously seen (Hanania and Zahniser, 2002). Subsequently, we studied whether differences in striatal levels of cocaine and/or striatal DAT function contribute to the differential behavioral sensitivity of ILS and ISS mice to cocaine.

\section{MATERIALS AND METHODS}

\section{Animals}

Adult (80-90 days old), male ILS and ISS mice were obtained from the Institute for Behavioral Genetics (Boulder, CO). The mice were housed in groups of five and exposed to a 12-h light-dark cycle with food and water available ad libitum. Experiments were conducted between 0700 and 1700 hours. All animal use procedures were in strict accordance with the NIH Guide for the Care and Use of Laboratory Animals and were approved by the Institu- tional Animal Care and Use Committee, University of Colorado Health Sciences Center.

\section{Locomotor Activity}

On day 1, drug-naïve ILS and ISS mice were transferred to the testing room, in which the lights were off for the duration of experimental testing. They were allowed to habituate for $60 \mathrm{~min}$ in clear acrylic open-field activity chambers $\left(16^{\prime \prime} \times 16^{\prime \prime} \times 15^{\prime \prime}\right)$ that were surrounded by an $8 \times 8$ photobeam frame (San Diego Instruments, San Diego, CA). Following habituation, mice were injected with saline and locomotor activity was monitored for $30 \mathrm{~min}$ before a second saline injection and behavioral monitoring for an additional $60 \mathrm{~min}$. On day 2, the same mice were again transferred to the darkened testing room. The habituation and injection procedures were repeated, with one exception: a randomly selected group of ILS and ISS mice were injected with (-)cocaine $\mathrm{HCl}(10,15$, or $20 \mathrm{mg} / \mathrm{kg}$, i.p.) instead of the second saline injection. Saline and cocaine (dissolved in saline) were administered i.p. at $1 \mathrm{ml} / 100 \mathrm{~g}$ body weight. The purpose of the first saline injection on day 2 was to ensure that both mouse strains exhibited similar baseline activity prior to cocaine treatment. Horizontal and vertical locomotor activities were determined from the number of consecutive photobeam breaks $/ 5 \mathrm{~min}$.

\section{Cocaine Levels}

A separate group of ILS and ISS mice underwent the same behavioral testing as described above for day 1 . On day 2, cocaine $(10,15$, or $20 \mathrm{mg} / \mathrm{kg}$, i.p.) was administered to all of the mice. At $30 \mathrm{~min}$ after cocaine injection, mice were killed by cervical dislocation and their striata were dissected and frozen at $-80^{\circ} \mathrm{C}$. Cocaine levels in striatum were measured using reverse-phase high-performance liquid chromatography coupled with ultraviolet detection as previously described (Gulley et al, 2003).

\section{$\left[{ }^{3} \mathrm{H}\right]$ WIN 35,428 Binding}

Drug-naïve ILS and ISS mice were killed by cervical dislocation. Their striata were dissected, homogenized in ice-cold assay buffer containing $30 \mathrm{mM} \mathrm{NaH} \mathrm{PO}_{4}, 15 \mathrm{mM}$ $\mathrm{Na}_{2} \mathrm{HPO}_{4}$, and $0.32 \mathrm{M}$ sucrose $(\mathrm{pH} 7.4)$, and centrifuged $\left(20000 \mathrm{~g} ; 4^{\circ} \mathrm{C}\right)$ for $20 \mathrm{~min}$. To generate indirect saturation binding isotherms, the pellets were re-suspended in assay buffer and were incubated for $60 \mathrm{~min}$ on ice in tubes containing $\left[{ }^{3} \mathrm{H}\right]$ WIN $35,428(\sim 4.2 \mathrm{nM})$ and various concentrations of unlabeled WIN $35,428\left(1 \times 10^{-5}-3.16 \times\right.$ $\left.10^{-10} \mathrm{M}\right)$. Nonspecific binding was determined in the presence of $30 \mu \mathrm{M}$ benztropine. Following rapid vacuum filtration over GF/B filters (Brandel Inc., Gaithersburg, MD) and three washes with ice-cold assay buffer, the radioactivity retained on the filters was measured by liquid scintillation spectrometry. Proteins were determined by the method of Bradford (1976) using bovine serum albumin as the standard. Affinity values $\left(\mathrm{IC}_{50}\right.$ and $\left.K_{\mathrm{i}}\right)$ and the total number of binding sites $\left(B_{\max }\right)$ were determined from nonlinear curve fitting (GraphPad Software, San Diego, CA), according to the method of DeBlasi et al (1989). 


\section{In Vivo Electrochemistry}

Exogenous DA clearance was measured as previously described (Gulley et al, 2003; Zahniser et al, 1999). Briefly, drug-naïve ILS and ISS mice were anesthetized with urethane to a deep surgical level (see Results) and placed in a stereotaxic frame. A small hole was drilled in the skull to allow insertion of an $\mathrm{Ag} / \mathrm{AgCl}$ reference electrode near the parietal cortex. A second hole was drilled overlying the left striatum $(1.2 \mathrm{~mm}$ anterior and $1.4 \mathrm{~mm}$ lateral to bregma; Franklin and Paxinos, 1997) to allow insertion of an electrode/micropipette assembly (lowered $2.5-4.0 \mathrm{~mm}$ ventral to the skull surface). The assembly consisted of a Nafion-coated carbon fiber electrode $(30 \mu \mathrm{m}$ diameter) attached to a single-barrel pipette (tip opening: $10-20 \mu \mathrm{m})$ such that tips were parallel and separated by $200-300 \mu \mathrm{m}$. Pipettes were filled with $200 \mu \mathrm{M}$ DA and $100 \mu \mathrm{M}$ ascorbic acid (in $0.1 \mathrm{M}$ phosphate-buffered saline, $\mathrm{pH}$ 7.4).

High-speed chronoamperometric measurements were made using an IVEC-10/FAST-12 system (Quanteon, LLC, Lexington, KY), which applied square-wave pulses of $0.00-0.55 \mathrm{~V}$ (with respect to reference) at a frequency of $5 \mathrm{~Hz}$. For each recording, a stable background current was established and set to zero prior to pressure-ejecting DA (5-20 psi for $0.1-2.5 \mathrm{~s})$ at calibrated volumes (10-300 $\mathrm{nl}$ ). Resulting oxidation currents were digitally integrated during the last $80 \mathrm{~ms}$ of each $100-\mathrm{ms}$ pulse, and signal changes were converted to DA concentrations based on an in vitro calibration (Gerhardt et al, 1984). Two signal parameters were analyzed from DA oxidation currents: maximal amplitude $\left(A_{\max }\right)$ and signal decay time $\left(\mathrm{T}_{80}\right)$. $A_{\max }$ reflects the maximal extracellular DA concentration detected, whereas $T_{80}$ is the time for the signal to rise to $A_{\max }$ and decay by $80 \%$. Both parameters are affected by DAT inhibitors (eg, Zahniser et al, 1999) and reflect changes in DA clearance (Cass et al, 1993; May et al, 1988).

For a given assembly and recording location, an ejection volume was chosen that resulted in $A_{\max }$ values of $0.75-3.85 \mu \mathrm{M}$. Ejections were made at 5-min intervals, and signals used to determine 'baseline' were established when $A_{\max }$ and $T_{80}$ time varied by $\leqslant 15 \%$ for two consecutive applications. At $4 \mathrm{~min}$ after the second baseline DA application, mice were injected (i.p.) with either saline or $10 \mathrm{mg} / \mathrm{kg}$ cocaine, and subsequent DA ejections were given $1 \mathrm{~min}$ later and then every $5 \mathrm{~min}$ for the next $30 \mathrm{~min}$. Data were normalized by obtaining a mean value for parameters during the two-point baseline period, setting this value as $100 \%$, and expressing all data (including the two baseline data points) as a percentage of baseline. In one ISS and one ILS mouse, recordings were obtained following both saline and cocaine injections; saline treatment occurred first and recordings were obtained at striatal locations that were separated by at least $200 \mu \mathrm{m}$. After experiments were completed, a small current was passed through the recording electrode to produce a marking lesion. The brain was then removed and stored in buffered formalin $(4 \% \mathrm{w} / \mathrm{v})$ for at least 3 days. Subsequently, coronal sections $(40 \mu \mathrm{m})$ at the level of the striatum were made using a vibratome, mounted to glass slides, and stained with cresyl violet to localize recording sites.

\section{Statistical Analysis}

Locomotor activity and rearing data were analyzed using analysis of variance (ANOVA) followed by Tukey's post hoc tests. Striatal cocaine levels, correlations between cocaine levels and locomotor activity and $\left[{ }^{3} \mathrm{H}\right]$ WIN 35,428 binding parameters were analyzed using Student's $t$-tests. For in vivo electrochemistry, baseline measures of DAT function (eg $A_{\max }, T_{80}$ ) were evaluated using unpaired Student's $t$-test, while strain differences in the effects of drug treatment were evaluated using a mixed, two-factor ANOVA followed by Tukey's post hoc tests. In all cases, $p<0.05$ was considered to be statistically significant.

\section{Materials}

Chemicals were purchased from either Sigma/RBI (St Louis, $\mathrm{MO}$ ) or Fisher (Pittsburgh, PA). (-)cocaine $\mathrm{HCl}$ and WIN 35,428 were obtained from the National Institute on Drug Abuse (RTI International, Research Triangle Park, NC). $\left[{ }^{3} \mathrm{H}\right]$ WIN 35,428 was purchased from PerkinElmer Life Sciences Products (Boston, MA).

\section{RESULTS}

\section{Effect of Novelty/Habituation on Locomotor Activity of ILS and ISS Mice}

The locomotor response of ILS and ISS mice to novelty was tested on day 1 during the first $30 \mathrm{~min}$ that the mice were in the open field chambers. As shown in Figure 1, ILS and ISS mice exhibited similar locomotor activity when placed in a novel environment. During this same time period on day 2, both mouse strains showed a significant decrease in locomotor activity relative to day 1 (Figure 1, inset). Between-strain analysis revealed that on day 2 ILS mice

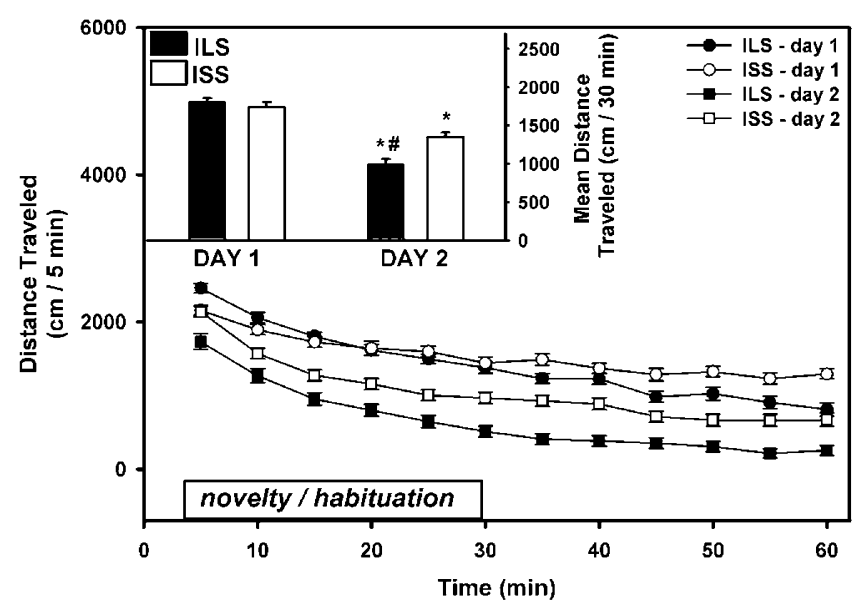

Figure I Time course for the effects of novelty/habituation on locomotor activity in ILS and ISS mice tested on two consecutive days. Inset: Locomotor activity (mean \pm SEM, $n=43-44$ ) during I-30 min, over which the data were averaged for the response to novelty. Two-way ANOVA revealed a significant difference in the response of ILS and ISS mice to novelty between days $I$ and $2((F(I,|7|)=\mid 1.07, p<0.05))$. Tukey's post hoc analysis found no significant differences in the response of ILS and ISS mice to novelty on day I ( $p>0.05)$. However, on day 2, ILS mice had significantly lower locomotor activity than ISS mice $(\# p<0.05)$. 


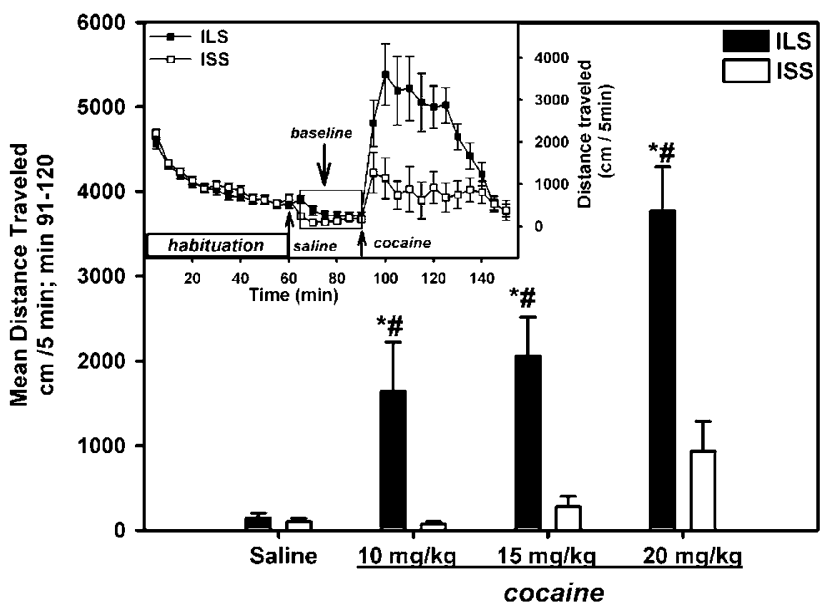

Figure 2 Dose-response relationships for locomotor activity induced by cocaine in habituated ILS and ISS mice on day 2 of the treatment protocol. Inset: Time-response for locomotor activity induced by injections of saline (first arrow) and cocaine $(20 \mathrm{mg} / \mathrm{kg}$, i.p.; second arrow). For the doseresponse analysis, locomotor activity was averaged between 91 and 120 min (mean \pm SEM; 9-13 mice/group). Two-way ANOVA revealed a significant genotype $\times$ drug interaction $((F(3,72)=3.94, p<0.05))$. Tukey's post hoc analysis indicated that ILS mice had higher locomotor cocaineinduced activity compared to the saline-treated group $(\# p<0.05)$ and that cocaine had no significant effect in ISS mice. At all doses of cocaine, ILS mice exhibited significantly higher locomotor activity compared to ISS mice $(* 0<0.05)$

exhibited significantly less activity compared to ISS mice, suggesting that ILS mice were more habituated to the testing apparatus (Figure 1, inset).

\section{Effect of Cocaine on Locomotor and Rearing Activities}

Following the habituation procedure, we then determined the dose-response relationship for cocaine-induced activation in the two mouse strains. To do this, ILS and ISS mice that had received two saline injections on day 1 were injected on day 2, first with saline and then with either saline or cocaine $(10,15$, or $20 \mathrm{mg} / \mathrm{kg}$, i.p.). The time course for cocaine $(20 \mathrm{mg} / \mathrm{kg})$-induced locomotor activity is shown in Figure 2 (inset). Compared to their saline-treated cohorts, cocaine significantly increased locomotor activity in ILS, but not ISS, mice (Figure 2). Between-strain analysis revealed that at all doses of cocaine tested, ILS mice exhibited higher locomotor activity, compared to ISS mice (Figure 2). The locomotor activity of cocaine-treated ISS mice was not significantly different from the saline-treated mice. However a nonsignificant trend toward increased activity was seen at $20 \mathrm{mg} / \mathrm{kg}$ cocaine. Strain differences in cocaine-induced locomotor activation were not due to differences in rearing activity, since no significant differences were observed in cocaine-induced rearing between ILS and ISS mice (data not shown). There were also no strain differences in the locomotor activity of ILS and ISS mice during the $30 \mathrm{~min}$ period following the first saline injection and prior to cocaine injection (data not shown). Thus, baseline differences in locomotor activity do not contribute to strain differences in cocaine-induced locomotor activity.

\section{Cocaine Levels in Striatum}

To test whether differences in cocaine pharmacokinetics between ILS and ISS mice might account for their differential behavioral sensitivity to the drug, we administered 10,15 , or $20 \mathrm{mg} / \mathrm{kg}$ (i.p.) cocaine to a separate group of habituated mice. These mice were killed $30 \mathrm{~min}$ after injection in order to measure striatal drug concentrations at the time of maximal behavioral activation. The results of these experiments are summarized in Table 1. No significant differences in striatal cocaine levels were observed between ILS and ISS mice at any of the doses. Furthermore, striatal cocaine levels and cocaine-induced locomotor activity were not significantly correlated within each mouse strain at any of the cocaine doses tested (Table 1).

\section{$\left[{ }^{3} \mathrm{H}\right]$ WIN 35,428 Binding in Striatum}

The affinity and number of DATs in striatal membranes were determined from indirect $\left[{ }^{3} \mathrm{H}\right]$ WIN 35,428 saturation curves (Figure 3). Affinities for the radioligand were similar between ILS and ISS mice ( $K_{\mathrm{i}}$ values: $9.5 \pm 1.1$ and $8.8 \pm 0.3 \mathrm{nM}$, respectively). However, ILS mice had a significantly lower number of DATs $(\sim 24 \%)$, compared to ISS mice ( $B_{\max }$ values: $2.9 \pm 0.2$ and $3.6 \pm 0.1 \mathrm{pmol} / \mathrm{mg}$ protein, respectively).

Table I Striatal Cocaine Levels and Correlations between Striatal Cocaine Levels and Cocaine-Stimulated Locomotor Activity in ILS and ISS Mice

\begin{tabular}{|c|c|c|c|c|}
\hline & $\mathbf{N}$ & Cocaine ( $10 \mathrm{mg} / \mathrm{kg})$ & Cocaine (15 mg/kg) & Cocaine $(20 \mathrm{mg} / \mathrm{kg})$ \\
\hline \multicolumn{5}{|c|}{ Striatal cocaine levels (ng/mg protein) } \\
\hline ILS & $6-8$ & $1.38 \pm 0.11$ & $2.10 \pm 0.08$ & $2.54 \pm 0.37$ \\
\hline ISS & $6-8$ & $1.29 \pm 0.32$ & $2.06 \pm 0.35$ & $2.22 \pm 0.22$ \\
\hline \multicolumn{5}{|c|}{ Correlations between striatal cocaine levels and locomotor activity $\left(r^{2}\right)$} \\
\hline ISS & $6-8$ & 0.283 & 0.025 & 0.018 \\
\hline
\end{tabular}

Two-way ANOVA revealed no significant differences in striatal cocaine levels between ILS and ISS mice at any of the cocaine doses tested $((F(2.32)=0.14, p>0.05))$. Within-strain analysis found no significant correlations between striatal cocaine levels and cocaine-induced locomotor activity at any dose of cocaine tested ( $p>0.05$ ). 


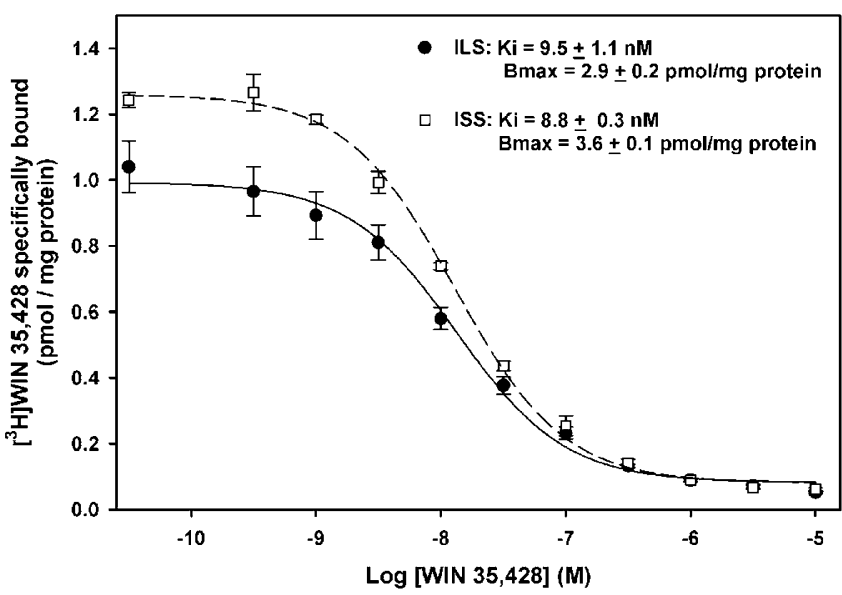

Figure $\left.3{ }^{3} \mathrm{H}\right]$ WIN 35,428/WIN 35,428 saturation binding isotherms in striatal membranes of drug-naïve ILS and ISS mice. $K_{i}$ and $B_{\max }$ values were derived from nonlinear curve fitting. While WIN 35,428 affinities were similar in both strains, ILS mice had significantly lower number of DATs compared to ISS mice (mean \pm SEM; $* 2<0.05, n=4$ mice/strain).

\section{In Vivo DAT Function in Striatum}

In preparation for in vivo chronoamperometric recordings, drug-naive mice were anesthetized with urethane. Not surprisingly, ISS mice required more urethane to maintain a surgical level of anesthesia (De Fiebre et al, 1992; Wehner et al, 1992). The mean dose used in ISS mice was $2.20 \pm 0.70 \mathrm{~g} / \mathrm{kg}$, whereas it was $1.67 \pm 0.04 \mathrm{~g} / \mathrm{kg}$ in ILS mice. This difference corresponded to $\sim 32 \%$ higher dose in ISS mice and was statistically significant $\left(t_{18}=7.18, p<0.001\right)$. In our sample of 12 recordings/strain from 10 mice/strain, there were no significant differences in baseline $A_{\max }$ $(\sim 2 \mu \mathrm{M})$ or in the volume of DA needed to attain these signal amplitudes (Table 2). However, there were strain differences in the signal decay time, or $T_{80}$, of exogenously applied DA. On average, DA was cleared $\sim 27 \%$ more slowly in ILS mice, compared to ISS mice (Table 2).

As shown in Figure $4 \mathrm{a}$, cocaine $(10 \mathrm{mg} / \mathrm{kg})$ had variable effects on $A_{\max }$ in the striatum of both ILS and ISS mice. While there was an overall trend for cocaine to increase $A_{\max }$ in both strains, this effect was not consistent within either group at any time point during the 30-min postinjection period. In contrast, measures of signal decay time were less variable (Figure $4 \mathrm{~b}$ ). In ILS mice, $T_{80}$ was significantly increased by $28 \%$, compared to baseline, in the 30-min period following injection. Despite the fact that cocaine did not significantly alter $T_{80}$ in ISS mice, there was

Table 2 In Vivo DAT Function during Baseline Recording

\begin{tabular}{lcll}
\hline & No. of mice/strain & ILS & ISS \\
\hline$A_{\max }(\mu \mathrm{M})$ & 10 & $2.16 \pm 0.20$ & $2.19 \pm 0.24$ \\
$T_{80}(\mathrm{~s})$ & 10 & $29.3 \pm 2.02 *$ & $21.4 \pm 2.75$ \\
DA ejection volume $(\mathrm{nl} / \mu \mathrm{M})$ & 10 & $64.0 \pm 16.1$ & $44.0 \pm 9.77$
\end{tabular}

Mean \pm SEM. $p<0.05$, ILS vs ISS mice $\left(t_{22}=2.31\right)$. Note that for each recording site, DA ejection volume is expressed as a ratio with $A_{\max }$ to normalize for between-recording differences in electrode sensitivity and in the construction of electrode/micropipette assemblies.
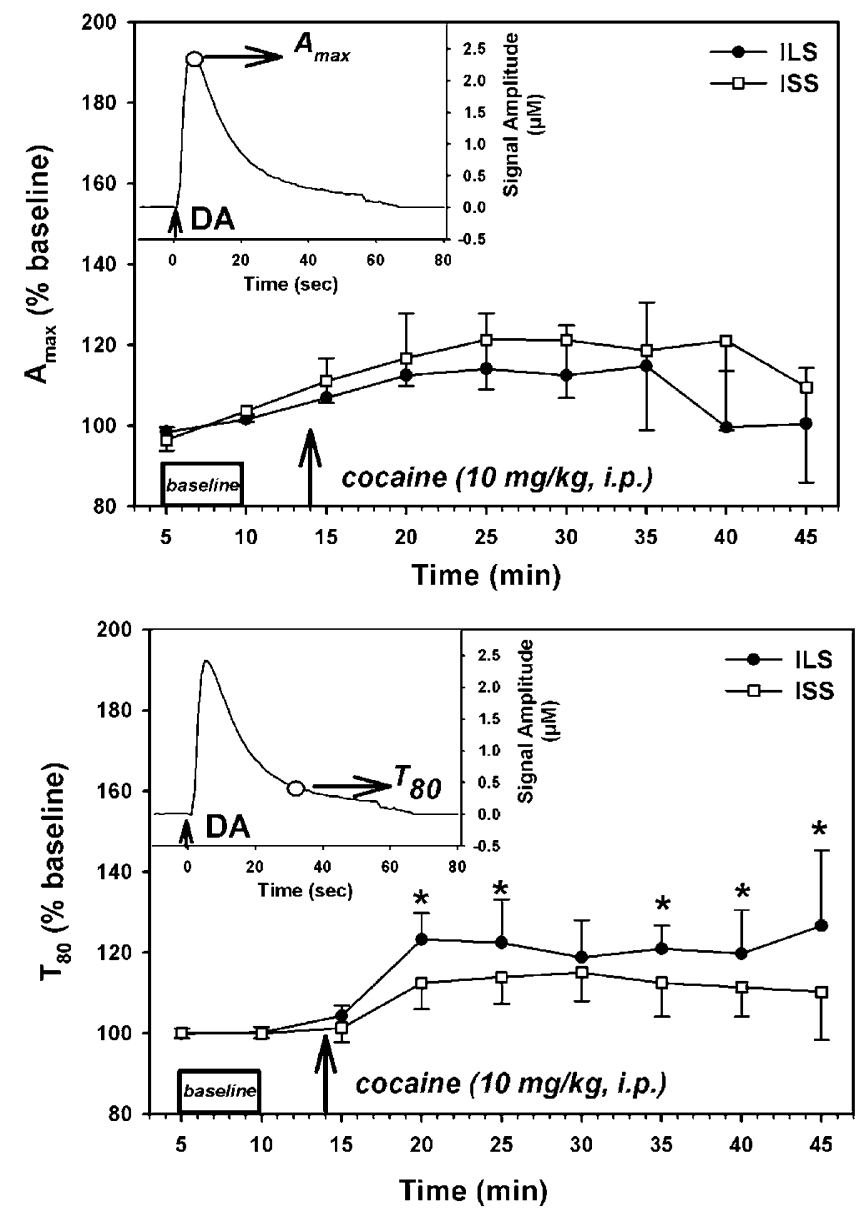

Figure 4 Effects of cocaine on the in vivo DA clearance parameters $A_{\max }$ (a) and $T_{80}(b)$ in dorsomedial striatum of ILS and ISS mice. Arrows indicate time of cocaine $(10 \mathrm{mg} / \mathrm{kg}$, i.p.) injection. Mean \pm SEM, $n=10$ mice/strain. (a) Two-way repeated measures ANOVA found that relative to baseline, cocaine trended to increase $A_{\max }$ in both strains, but this was not statistically significant $(F(8,77)=0.1 \mathrm{I}), p>0.05))$. (b) Two-way repeated measures ANOVA found no significant between-strain differences in the effects of cocaine on $\left.\left.T_{80}(F(8,77)=0.43), p>0.05\right)\right)$. However, cocaine significantly increased signal decay time by up to $28 \%$ over baseline in ILS, but not ISS, mice $(* p<0.05)$. Insets: Representative chronoamperometric recordings of in vivo DA clearance in dorsomedial striatum indicating the parameters analyzed $\left(A_{\max }(a)\right.$ and $\left.T_{80}(b)\right)$ from the electrochemical DA oxidation signals.

a trend for $T_{80}$ to increase following cocaine injection. Therefore, no significant strain differences were found in the effects of cocaine. In both ILS and ISS mice, saline injection did not significantly alter either $A_{\max }$ or $T_{80}$ (data not shown).

\section{DISCUSSION}

The results from this study confirm our previous findings and indicate that ILS mice, compared to ISS mice, show consistently greater responsiveness to the locomotorstimulant effects of cocaine when either short $(60 \mathrm{~min}$; Hanania and Zahniser, 2002) or prolonged (two 60-min) habituation sessions are used. In addition, we provide evidence for differences in striatal DAT function and inhibition by cocaine in the two mouse strains, likely reflecting the lower number of striatal DATs in the ILS mice. 
These differences could help to explain the differential sensitivity of ILS and ISS mice to cocaine-induced locomotor activation.

In rodents, habituation to the testing environment has been shown to influence the locomotor-stimulant effects of various drugs of abuse (Koechling et al, 1991; Mazurski and Beninger, 1987). For example, LS and SS mice tested with saline on day 1 and cocaine on day 2 exhibited similar cocaine-induced locomotor stimulation (Jones et al, 1991). However, George and Ritz (1990) found that without habituation, cocaine induced higher locomotor activity in SS mice than in LS mice, and De Fiebre et al (1989) found that LS mice had higher cocaine-induced arm entries when they were placed in a Y-maze. We have previously found that following a brief habituation period, cocaine enhances locomotor activity of ILS mice to a greater extent than ISS mice (Hanania and Zahniser, 2002). The disparate results (De Fiebre et al, 1989; George and Ritz, 1990; Jones et al, 1991; Hanania and Zahniser, 2002) suggest that environmental factors could be important in the differential sensitivity of LS/SS and ILS/ISS mice to the locomotorstimulant effects of cocaine. Thus, differences in exploratory behaviors in a novel environment between these mice might explain the contradictory results. However, in the current study, we found that treating ILS and ISS mice with saline in the activity chambers on the first test day did not alter their sensitivity to the locomotor-stimulant effects of either saline (ILS $=$ ISS) or cocaine (ILS $>$ ISS) on the second test day. It is also noteworthy that in a preliminary study testing locomotor activation in four ILS and three ISS mice with no previous experience in the testing environment (ie, no habituation), ILS and ISS mice traveled an average of 5000 and $3000 \mathrm{~cm}$, respectively, during the 20-min period following a $10 \mathrm{mg} / \mathrm{kg}$ cocaine injection ( $\mathrm{T}$ Hanania and NR Zahniser, unpublished observations). Thus, it is unlikely that the disparate results in the literature are due to differences in novelty responses in either the ILS/ISS or LS/ SS strains. Conflicting results in inbred $v s$ outbred strains may instead be due to genetic differences that likely resulted from the inbreeding process. In addition, our data support previous studies showing that response to novelty does not influence the response of rats to acute cocaine (Gulley et al, 2003; Sabeti et al, 2002; also see Chefer et al, 2003).

Because we used a multiple-day habituation procedure that included successive saline injections, it is possible that the behavioral responses of ILS and ISS mice to cocaine were influenced by the unexpected outcome of receiving a drug on the second test day, rather than another saline injection. In other words, mice in the two strains might differ in the extent to which they form and/or express learned associations between the environment and expected outcomes. While this issue has not been addressed specifically, conditioned behavioral responses have been assessed in the outbred lines. For example, LS and SS mice exhibit similar learning and subsequent maintenance of fixed-ratio responding for water in an operant-reinforcement paradigm (Elmer and George, 1994). In addition, when ILS and ISS mice are given cocaine after a brief habituation period, ILS mice still exhibit greater cocaineinduced locomotor behavior (Hanania and Zahniser, 2002). Thus, it is unlikely that strain differences in the response to unexpected outcomes can explain the robust differences in behavior we observed previously (Hanania and Zahniser, 2002) and in the current study.

The differential responsiveness of ILS and ISS mice to cocaine-induced locomotion is not influenced by differences in striatal cocaine pharmacokinetics. As shown in Table 1, all doses of cocaine tested resulted in similar striatal cocaine levels in the two mouse strains. Furthermore, there was no significant correlation between striatal cocaine levels and cocaine-stimulated locomotor activity within each mouse strain. Our findings are in agreement with other reports showing no differences in brain cocaine levels in mice or rats, despite their differential sensitivity to cocaine-induced locomotion (Ruth et al, 1988) or to developing cocaine self-administration behavior (Piazza et al, 2000; Rocha et al, 1998). It is possible, however, that there are strain differences in cocaine levels in brain regions other than the striatum that could influence the differential sensitivity of ILS and ISS mice to cocaine-induced locomotion. For example, Wiener and Reith (1990) found a significant correlation between cocaine-induced locomotor activity and cocaine levels in mouse cortex. In addition, we recently found a small $\left(r^{2}=0.18\right)$, but significant, correlation between cocaine-induced locomotor activity and cocaine levels in NAc, but not dorsal striatum, of rats (Gulley et al, 2003). However, since we have previously shown that other DAT inhibitors such as amphetamine and GBR 12909 also stimulate higher locomotor activity in ILS mice, compared to ISS mice (Hanania and Zahniser, 2002), it is unlikely that pharmacokinetics alone can explain the differential behavioral sensitivity of ILS and ISS mice to cocaine.

Inhibition of striatal DAT is clearly critical for psychostimulant-induced behaviors. In DAT knockdown mice that express $10 \%$ of striatal DAT or in DAT knockout mice, amphetamine and cocaine either attenuate or fail to stimulate locomotor activation (Giros et al, 1996; Sora et al, 1998; Spielewoy et al, 2001; Trinh et al, 2003; Zhuang et al, 2001). Here, we found that ILS mice have 24\% fewer striatal DAT binding sites, compared to ISS mice. Based on occupation theory, cocaine would be expected to occupy the same percentage of DATs in ILS and ISS mice since their DATs have the same affinity for cocaine. However, the higher number of DATs in the ISS mice may represent 'spare transporters' so that lower doses of cocaine, such as used here, may cause significant increases in extracellular DA and thereby greater locomotor activation only in the ILS mice. Janowsky et al (2001) found that DAT expression in the striatum is genetically correlated with cocaine- and methamphetamine-induced locomotor activity in BXD recombinant inbred mice. Furthermore, the same group reported an inverse correlation between the number of striatal DATs and locomotor activity induced by cocaine $(10 \mathrm{mg} / \mathrm{kg})$. These findings are consistent with our results showing higher cocaine-stimulated locomotor activity and lower striatal DATs in ILS mice. However, another plausible explanation would be that striatal extracellular DA concentrations differ between ILS and ISS mice. The modeling results of $\mathrm{Wu}$ et al (2001a, b) point to a role for differential DA release, rather than DAT number, being the critical determinant for sensitivity to cocaine. If ILS mice have higher extracellular DA concentrations than ISS mice, then the transporters in ILS mice would be more readily 
saturated after cocaine inhibition, leading to enhanced drug effects. This possibility remains to be explored.

It was important to test whether the ILS/ISS strain differences in striatal DAT number had functional consequences. We and others have used detailed kinetic analyses to show that in vivo electrochemical measures of DA signal decay time reflect transporter activity (Cass et al, 1993; May et al, 1988; Wu et al, 2001a,b). Here, we used in vivo high-speed chronoamperometry and found that exogenous DA applied in the striatum was cleared at an $\sim 27 \%$ slower rate in ILS mice, compared to ISS mice. These baseline differences in DAT function are consistent with the differences we observed in DAT number between the two strains. It is noteworthy that in these experiments, ILS mice required $\sim 32 \%$ less urethane than ISS mice to maintain a surgical level of anesthesia. However, this strain difference in total anesthetic dose, which has been demonstrated previously (De Fiebre et al, 1992; Wehner et al, 1992), is not surprising given that these animals were selectively bred for their sedative response to ethanol (Markel et al, 1995; McClearn and Kakihana, 1981). Furthermore, it is unlikely to account for the differences we observed in DAT activity because urethane anesthesia has no effect on exogenous DA clearance in rats (Sabeti et al, 2003).

Despite the fact that cocaine significantly increased $T_{80}$ from baseline in striata of ILS mice, no significant effects of cocaine on either $A_{\max }$ or $T_{80}$ were observed between the two strains. These results are consistent with the results we obtained in in vitro experiments showing no strain difference in cocaine inhibition of striatal $\left[{ }^{3} \mathrm{H}\right] \mathrm{DA}$ uptake (Hanania and Zahniser, 2002). In the present study, we analyzed the effects of cocaine on DAT activity using a dose $(10 \mathrm{mg} / \mathrm{kg})$ that produces significant locomotor activation in ILS, but not ISS, mice. It is possible that significant strain differences in cocaine-induced inhibition of DAT function might be observed if higher doses were tested. Regardless, the present analysis of cocaine-induced changes in DAT function, especially when considered along with the between-strain differences we observed in baseline DAT activity, suggests that differences in DAT number and function contribute to, but are not solely responsible for, the differential behavioral effects of cocaine between ILS and ISS mice.

In addition to DAT, cocaine inhibits the NE transporter (NET), and NE can influence cocaine-induced locomotor activity. For example, inhibition of $\alpha_{1}$-adrenergic receptors attenuates cocaine-stimulated activity in rats (Drouin et al, 2002); at lower doses, the selective DAT inhibitor GBR 12783 stimulates less locomotor activation in $\alpha_{1 \mathrm{~b}}$ knockout mice than in wild-type mice (Villégier et al, 2003). In NET knockout mice, i.p. cocaine injection results in greater locomotor stimulation than in wild-type mice (Xu et al, 2000) whereas i.v. cocaine administration induces less locomotor stimulation, compared to wild-type mice (Mead et al, 2002). The opposing results in these studies could be due to the different routes of cocaine administration, and subsequent differences in drug metabolism and distribution (Mead et al, 2002). Alternatively, the stress caused by an i.p. injection could increase NE levels to a greater extent than an i.v. injection, and this could account for the differential behavioral responses of NET knockout mice to cocaine (Pacak et al, 1995; Mead et al, 2002; Reith et al, 1997). In any case, these results underscore the potential contribution of NET to differential cocaine activation. Studies from our laboratory found that ILS mice have $\sim 30 \%$ fewer brain NETs than ISS mice (HM Haughey, AL Kaiser, TE Johnson, B Bennett, JM Sikela, NR Zahniser, unpublished observations). If fewer NETs result in supersensitivity to systemic cocaine-induced locomotor activity ( $\mathrm{Xu}$ et al, 2000), then lower NET number in ILS mice might also contribute to the greater behavioral sensitivity of these mice to the stimulant effects of cocaine.

Cocaine also inhibits the 5-HT transporter (SERT). Interestingly, SERT antagonists can substitute for cocaine in conditioned place preference studies in DAT knockout mice (Mateo et al, 2004) and can modulate the locomotorstimulant effects of cocaine in rodents (Bubar et al, 2003; Reith et al, 1991). Previously, we found no significant differences in the number of cortical SERTs between ILS and ISS mice (Hanania et al, 2002). However, preliminary data show differential strain modulation of cocaine-induced activity by the SERT inhibitor fluoxetine, as well as by the various 5-HT receptor antagonists ( $\mathrm{T}$ Hanania, AC McCreary, DO Salaz, AM Lyons, NR Zahniser, unpublished observations). Therefore, strain differences in the 5-HT system could also contribute to the differential behavioral sensitivity of ILS and ISS mice to cocaine.

Although cocaine may increase DA levels and locomotor activity to a greater extent in ILS mice via direct inhibition of DAT, both NE and 5-HT systems interact with the DA system, as well as with each other, to modulate psychostimulant-induced locomotor activity and DA neurotransmission (Auclair et al, 2002; Broderick and Phelix, 1997; Mateo et al, 2004; Munoz et al, 2003; Shi et al, 2000). Thus, cocaine inhibition of NET and SERT indirectly increasing DA levels to a greater extent in ILS mice may also contribute to the differential locomotor-stimulant effects of cocaine in ILS and ISS mice. These possibilities remain to be examined.

In summary, our data suggest that differences in DAT number and function contribute to the differential initial sensitivity of ILS and ISS mice to the locomotor-stimulant effects of cocaine. The opposing responsiveness of these mice to cocaine makes them a valuable model for studying not only DA systems, but also other monoamine systems, that potentially contribute to this phenotype, as well as for elucidating genes that mediate initial sensitivity to cocaine.

\section{ACKNOWLEDGEMENTS}

We thank Ms Anne Lyons for her help with the behavioral experiments. This work was supported by NIH AA03527, DA04216, and DA15050.

\section{REFERENCES}

Auclair A, Cotecchia S, Glowinski J, Tassin JP (2002). D-Amphetamine fails to increase extracellular dopamine levels in mice lacking alpha 1b-adrenergic receptors: relationship between functional and nonfunctional dopamine release. $J$ Neurosci 22: 9150-9154.

Bergstrom HC, Palmer AA, Wood RD, Burkhart-Kasch S, McKinnon CS, Phillips TJ (2003). Reverse selection for differential response to the locomotor stimulant effects of ethanol provides evidence for pleiotropic genetic influence on 
locomotor response to other drugs of abuse. Alcohol Clin Exp Res 27: 1535-1547.

Bradford MM (1976). A rapid and sensitive method for the quantitation of microgram quantities of protein utilizing the principle of protein-dye binding. Anal Biochem 72: 248-254.

Broderick PA, Phelix CF (1997). Serotonin (5-HT) within dopamine reward circuits signals open-field behavior II. Basis for 5-HT-DA interaction in cocaine dysfunctional behavior. Neurosci Biobehav Rev 21: 227-260.

Bubar MJ, McMahon LR, De Deurwaerdere P, Spampinato U, Cunningham KA (2003). Selective serotonin reuptake inhibitors enhance cocaine-induced locomotor activity and dopamine release in the nucleus accumbens. Neuropharmacology 44: 342-353.

Cadoret RJ, Troughton E, O’Gorman TW, Heywood E (1986). An adoption study of genetic and environmental factors in drug abuse. Arch Gen Psychiat 43: 1131-1136.

Cass WA, Zahniser NR, Flach KA, Gerhardt GA (1993). Clearance of exogenous dopamine in rat dorsal striatum and nucleus accumbens: role of metabolism and effects of locally applied uptake inhibitors. J Neurochem 61: 2269-2278.

Chefer VI, Zakharova I, Shippenberg TS (2003). Enhanced responsiveness to novelty and cocaine is associated with decreased basal dopamine uptake and release in the nucleus accumbens: quantitative microdialysis in rats under transient conditions. J Neurosci 23: 3076-3084.

DeBlasi A, O’Reilly K, Motulsky HJ (1989). Calculating receptor number from binding experiments using same compound as radioligand and competitor. Trends Pharmacol Sci 10: 227-229.

De Fiebre CM, Marley RJ, Miner LL, de Fiebre NE, Wehner JM, Collins AC (1992). Classical genetic analyses of responses to sedative-hypnotic drugs in crosses derived from long-sleep and short-sleep mice. Alcohol Clin Exp Res 16: 511-521.

De Fiebre CM, Ruth JA, Collins AC (1989). Differential sensitivity of long-sleep and short-sleep mice to high doses of cocaine. Pharmacol Biochem Behav 34: 887-893.

DeFries JC, Wilson JR, Erwin VG, Petersen DR (1989). LS $\times$ SS recombinant inbred strains of mice: initial characterization. Alcohol Clin Exp Res 13: 196-200.

Delfs JM, Schreiber L, Kelley AE (1990). Microinjection of cocaine into the nucleus accumbens elicits locomotor activation in the rat. J Neurosci 10: 303-310.

Di Chiara G, Imperato A (1988). Drugs abused by humans preferentially increase synaptic dopamine concentrations in the mesolimbic system of freely moving rats. Proc Natl Acad Sci USA 85: 5274-5278.

Drouin C, Darracq L, Trovero F, Blanc G, Glowinski J, Cotecchia S et al (2002). Alphalb-adrenergic receptors control locomotor and rewarding effects of psychostimulants and opiates. J Neurosci 22: 2873-2884.

Dudek BC, Phillips TJ (1990). Distinctions among sedative, disinhibitory, and ataxic properties of ethanol in inbred and selectively bred mice. Psychopharmacology 101: 93-99.

Elmer GI, George FR (1994). Operant rate depressant effects of ethanol in mice selectively bred for differential neurosensitivity to ethanol. J Addict Dis 13: 9-19.

Franklin KBF, Paxinos G (1997). The Mouse Brain in Stereotaxic Coordinates. Academic Press: New York.

George FR, Ritz MC (1990). Cocaine produces locomotor stimulation in SS but not LS mice: relationship to dopaminergic function. Psychopharmacology 101: 18-22.

Gerhardt GA, Oke AF, Nagy G, Moghaddam B, Adams RN (1984). Nafion-coated electrodes with high selectivity for CNS electrochemistry. Brain Res 290: 390-395.

Giros B, Jaber M, Jones SR, Wightman RM, Caron MG (1996). Hyperlocomotion and indifference to cocaine and amphetamine in mice lacking the dopamine transporter. Nature 379: 606-612.
Gulley JM, Hoover BR, Larson GA, Zahniser NR (2003). Individual differences in cocaine-induced locomotor activity in rats: behavioral characteristics, cocaine pharmacokinetics, and the dopamine transporter. Neuropsychopharmacology 28: 2089-2101.

Haertzen CA, Kocher TR, Miyasato K (1983). Reinforcements from the first drug experience can predict later drug habits and/or addiction: results with coffee, cigarettes, alcohol, barbiturates, minor and major tranquilizers, stimulants, marijuana, hallucinogens, heroin, opiates and cocaine. Drug Alcohol Depend 11: 147-165.

Hanania T, McCreary AC, Haughey HM, Salaz DO, Zahniser NR (2002). MK-801- and ethanol-induced activity in inbred longsleep and short-sleep mice: dopamine and serotonin systems. Eur J Pharmacol 457: 125-135.

Hanania T, Zahniser NR (2002). Locomotor activity induced by noncompetitive NMDA receptor antagonists versus dopamine transporter inhibitors: opposite strain differences in inbred long-sleep and short-sleep mice. Alcohol Clin Exp Res 26: 431-440.

He M, Shippenberg TS (2000). Strain differences in basal and cocaine-evoked dopamine dynamics in mouse striatum. $J$ Pharmacol Exp Ther 293: 121-127.

Heusner CL, Hnasko TS, Szczypka MS, Liu Y, During MJ, Palmiter RD (2003). Viral restoration of dopamine to the nucleus accumbens is sufficient to induce a locomotor response to amphetamine. Brain Res 980: 266-274.

Janowsky A, Mah C, Johnson RA, Cunningham CL, Phillips TJ, Crabbe JC et al (2001). Mapping genes that regulate density of dopamine transporters and correlated behaviors in recombinant inbred mice. J Pharmacol Exp Ther 298: 634-643.

Jones BC, Campbell AD, Radcliffe RA, Erwin VG (1991). Cocaine actions, brain levels and receptors in selected lines of mice. Pharmacol Biochem Behav 40: 941-948.

Koechling UM, Smith BR, Amit Z (1991). Effects of GABA antagonists and habituation to novelty on ethanol-induced locomotor activity in mice. Alcohol Alcoholism 26: 315-322.

Kuhar MJ, Ritz MC, Boja JW (1991). The dopamine hypothesis of the reinforcing properties of cocaine. Trends Neurosci 14: 299-302.

Luthar SS, Rounsaville BJ (1993). Substance misuse and comorbid psychopathology in a high-risk group: a study of siblings of cocaine misusers. Int J Addict 28: 415-434.

Mao L, Wang JW (2000). Distinct inhibition of acute cocainestimulated motor activity following microinjection of a group III metabotropic glutamate receptor agonist into the dorsal striatum of rats. Pharmacol Biochem Behav 67: 93-101.

Markel PD, DeFries JC, Johnson TE (1995). Use of repeated measures in an analysis of ethanol-induced loss of righting reflex in inbred long-sleep and short-sleep mice. Alcohol Clin Exp Res 19: 299-304.

Mateo Y, Budygin EA, John CE, Jones SR (2004). Role of serotonin in cocaine effects in mice with reduced dopamine transporter function. Proc Natl Acad Sci USA 101: 372-377.

May LJ, Kuhr WG, Wightman RM (1988). Differentiation of dopamine overflow and uptake processes in the extracellular fluid of the rat caudate nucleus with fast-scan in vivo voltammetry. J Neurochem 51: 1060-1069.

Mazurski EJ, Beninger RJ (1987). Environment-specific conditioning and sensitization with (+)-amphetamine. Pharmacol Biochem Behav 27: 61-65.

McClearn GE, Kakihana R (1981). Selective breeding for ethanol sensitivity: LS and SS mice. In: McClearn GE, Deitrich RA, Erwin VG (eds). Development of Animal Models as Pharmacogenetic Tools. US Government Printing Office: Washington, DC. pp 147-159.

Mead AN, Rocha BA, Donovan DM, Katz JL (2002). Intravenous cocaine induced-activity and behavioural sensitization in 
norepinephrine-, but not dopamine-transporter knockout mice. Eur J Neurosci 16: 514-520.

Merikangas KR, Stolar M, Stevens DE, Goulet J, Preisig MA, Fenton B et al (1998). Familial transmission of substance use disorders. Arch Gen Psychiatry 55: 973-979.

Miner LL (1997). Cocaine reward and locomotor activity in C57BL/ $6 \mathrm{~J}$ and $129 / \mathrm{SvJ}$ inbred mice and their F1 cross. Pharmacol Biochem Behav 58: 25-30.

Morse AC, Erwin VG, Jones BC (1995). Pharmacogenetics of cocaine: a critical review. Pharmacogenetics 5: 183-192.

Munoz A, Lopez-Real A, Labandeira-Garcia JL, Guerra MJ (2003). Interaction between the noradrenergic and serotonergic systems in locomotor hyperactivity and striatal expression of Fos induced by amphetamine in rats. Exp Brain Res 153: 92-99.

Pacak K, Palkovits M, Kvetnansky R, Yadid G, Kopin IJ, Goldstein DS (1995). Effects of various stressors on in vivo norepinephrine release in the hypothalamic paraventricular nucleus and on the pituitary-adrenocortical axis. Ann NY Acad Sci 771: 115-130.

Phillips TJ, Burkhart-Kasch S, Gwiazdon CC, Crabbe JC (1992). Acute sensitivity of FAST and SLOW mice to the effects of abused drugs on locomotor activity. J Pharmacol Exp Ther 261: 525-533.

Phillips TJ, Huson MG, McKinnon CD (1996). Localization of genes maping acute and sensitized locomotor responses to cocaine in BXD/Ty recombinant inbred mice. J Neurosci 18: 3023-3034

Piazza PV, Deroche-Gamonent V, Rouge-Pont F, Le Moal M (2000). Vertical shifts in self-administration dose-response functions predict a drug-vulnerable phenotype predisposed to addiction. J Neurosci 20: 4226-4232.

Reith ME, Li MY, Yan QS (1997). Extracellular dopamine, norepinephrine, and serotonin in the ventral tegmental area and nucleus accumbens of freely moving rats during intracerebral dialysis following systemic administration of cocaine and other uptake blockers. Psychopharmacology 134: 309-317.

Reith ME, Wiener HL, Fischette CT (1991). Sertraline and cocaineinduced locomotion in mice. I. Acute studies. Psychopharmacology 103: 297-305.

Ritz MC, Cone EJ, Kuhar MJ (1990). Cocaine inhibition of ligand binding at dopamine, norepinephrine and serotonin transporters: a structure-activity study. Life Sci 46: 635-645.

Rocha BA, Odom LA, Barron BA, Ator R, Wild SA, Forster MJ (1998). Differential responsiveness to cocaine in C57BL/6J and DBA/2J mice. Psychopharmacology 138: 82-88.

Ruth JA, Ullman EA, Collins AC (1988). An analysis of cocaine effects on locomotor activities and heart rate in four inbred mouse strains. Pharmacol Biochem Behav 29: 157-162.

Sabeti J, Gerhardt GA, Zahniser NR (2002). Acute cocaine differentially alters accumbens and striatal dopamine clearance in low and high cocaine locomotor responders: behavioral and electrochemical recordings in freely moving rats. J Pharmacol Exp Ther 302: 1201-1211.

Sabeti J, Gerhardt GA, Zahniser NR (2003). Chloral hydrate and ethanol, but not urethane, alter the clearance of exogenous dopamine recorded by chronoamperometry in striatum of unrestrained rats. Neurosci Lett 343: 9-12.

Shi WX, Pun CL, Zhang XX, Jones MD, Bunney BS (2000). Dual effects of $\mathrm{D}$-amphetamine on dopamine neurons mediated by dopamine and nondopamine receptors. J Neurosci 20: 3504-3511.

Smith DE (1986). Cocaine-alcohol abuse: epidemiological, diagnostic and treatment considerations. J Psychoactive drugs 18: 117-129.

Sora I, Wichems C, Takahashi N, Li XF, Zeng Z, Revay R et al (1998). Cocaine reward models: conditioned place preference can be established in dopamine- and in serotonin-transporter knockout mice. Proc Natl Acad Sci USA 95: 7699-7704.

Spielewoy C, Biala G, Roubert C, Hamon M, Betancur C, Giros B (2001). Hypolocomotor effects of acute and daily D-amphetamine in mice lacking the dopamine transporter. Psychopharmacology 159: 2-9.

Tolliver BK, Carney JM (1995). Locomotor stimulant effects of cocaine and novel cocaine analogs in DBA/2J and C57BL/6J inbred mice. Pharmacol Biochem Behav 50: 163-169.

Trinh JV, Nehrenberg DL, Jacobson JP, Caron MG, Wetsel WC (2003). Differential psychostimulant-induced activation of neural circuits in dopamine transporter knockout and wild type mice. Neuroscience 118: 297-310.

Villégier AS, Drouin C, Bizot JC, Marien M, Glowinski J, Colpaert F et al (2003). Stimulation of postsynaptic alphalb- and alpha2adrenergic receptors amplifies dopamine-mediated locomotor activity in both rats and mice. Synapse 50: 277-284.

Wehner JM, Pounder JI, Parham C, Collins AC (1992). A recombinant inbred strain analysis of sleep-time responses to several sedative-hypnotics. Alcohol Clin Exp Res 16: 522-528.

Wiener HL, Reith ME (1990). Correlation between cocaine-induced locomotion and cocaine disposition in the brain among four inbred strains of mice. Pharmacol Biochem Behav 36: 699-701.

Willuhn I, Sun W, Steiner H (2003). Topography of cocaineinduced gene regulation in the rat striatum: relationship to cortical inputs and role of behavioral context. Eur J Neurosci 17: 1053-1066.

Womer DE, Jones BC, Erwin VG (1994). Characterization of dopamine transporter and locomotor effects of cocaine, GBR 12909, epidepride, and SCH 23390 in C57BL and DBA mice. Pharmacol Biochem Behav 48: 327-335.

Wu Q, Reith ME, Kuhar MJ, Carroll FI, Garris PA (2001a). Preferential increases in nucleus accumbens dopamine after systemic cocaine administration are caused by unique characteristics of dopamine neurotransmission. J Neurosci 21: 6338-6347.

Wu Q, Reith ME, Wightman RM, Kawagoe KT, Garris PA (2001b). Determination of release and uptake parameters from electrically evoked dopamine dynamics measured by real-time voltammetry. J Neurosci Methods 112: 119-133.

Xu F, Gainetdinov RR, Wetsel WC, Jones SR, Bohn LM, Miller GW et al (2000). Mice lacking the norepinephrine transporter are supersensitive to psychostimulants. Nat Neurosci 3: 465-471.

Zahniser NR, Larson GA, Gerhardt GA (1999). In vivo dopamine clearance rate in rat striatum: regulation by extracellular dopamine concentration and dopamine transporter inhibitors. J Pharmacol Exp Ther 289: 266-277.

Zhuang X, Oosting RS, Jones SR, Gainetdinov RR, Miller GW, Caron MG et al (2001). Hyperactivity and impaired response habituation in hyperdopaminergic mice. Proc Natl Acad Sci USA 98: 1982-1987. 